\title{
Mn-nabohacené tetraedrity z rumunských ložisek Cavnic, Botești a Săcărâmb
}

\author{
Mn-enriched tetrahedrites from Romanian deposits Cavnic, Botești and Săcărâmb
}

\author{
Dalibor VelebiL*, JiŘí Sejkora a ZdenĚk Dolníček \\ Národní muzeum, mineralogicko-petrologické oddělení, Cirkusová 1740, 19300 Praha 9; \\ ${ }^{*}$ e-mail: dalibor.velebil@nm.cz
}

VeLebil D, SeJKora J, Dolní̌EK Z (2020) Mn-nabohacené tetraedrity z rumunských ložisek Cavnic, Botești a Săcărâmb. Bull Mineral Petrolog 28(1): 161-169 ISSN 2570-7337

\begin{abstract}
Eight samples of members of tetrahedrite group from Romanian deposits were examined in terms of their chemical composition studied by means of electron microprobe; five samples from Cavnic, two from Botești and one from Săcărâmb. Mean composition of all samples is corresponding to tetrahedrite-( $\mathrm{Zn})$ and most of them contain Mn. The three Cavnic tetrahedrites contain up to 0.17 apfu, the two Botești samples contain up to 0.42 apfu and the Săcărâmb sample up to 0.83 apfu $\mathrm{Mn}$. Pb and Sn were present at levels up to 0.01 apfu but entering of $\mathrm{Pb}$ and $\mathrm{Sn}$ into the crystal structure of tetrahedrite group minerals is questionable. Though the significant presence of Te is characteristic for the Botești and Săcărâmb deposits, the studied tetrahedrites from these deposits are virtually Te-free (only locally contents of Te up to 0.05 apfu were detected in one sample).
\end{abstract}

Key words: tetrahedrite, chemical composition, manganese, Cavnic, Botești, Săcărâmb, Romania

Obdrženo 15. 4. 2020; prijiato 5. 6. 2020

\section{Úvod}

Minerály skupiny tetraedritu jako jedny z nejběžnějších sulfosolí na různých typech hydrotermálních rudních ložisek (Biagioni et al. 2020a) patří k dưležitým těženým rudám $\mathrm{Cu}, \mathrm{Ag}$ a v menší míre i Hg. Z jiného pohledu jsou jejich synteticky připravené analogy studovány jako elektron-deficientní polovodiče (Suekuni et al. 2014) pro termoelektrické využití (Lu et al. 2013; Suekuni et al. 2013; Chetty et al. 2015) stejně jako potenciální materiály pro využití ve fotovoltaických zařízeních (van Embden et al. 2013).

Skupina tetraedritu patří mezi nejvíce komplexní izotypní série mezi sulfosolemi v prírodě, což je vyvoláno zejména řadou možných izo- a heterovalentních substitucí (Moëlo et al. 2008). Obecný vzorec minerálů této skupiny je možno zjednodušeně vyjádřit jako ${ }^{\mathrm{M}(2)} \mathrm{A}_{6}{ }^{\mathrm{M}(1)}\left(\mathrm{B}_{4} \mathrm{C}_{2}\right)_{\Sigma 6}{ }^{\mathrm{X}(3)}$ $\mathrm{X}_{4}^{\mathrm{s}(1)} \mathrm{Y}_{12}{ }^{\mathrm{s}(2) \mathrm{Z}_{1}}$, kde $\vee A$ pozici vystupuji $\mathrm{Cu}^{+}, \mathrm{Ag}^{+}, \square$ (vakance); možné jsou ve spojení s vakancemi v pozici $Z$ též skupiny $\left(\mathrm{Ag}_{6}\right)^{4+}$; v pozici $\mathrm{B}$ pak $\mathrm{Cu}^{+}$nebo $\mathrm{Ag}^{+}$v tetraedrické koordinaci; pozice $C$ je obecně obsazována dvojmocnými prvky (typicky $\mathrm{Zn}^{2+}$ nebo $\mathrm{Fe}^{2+}$, ale také $\mathrm{Hg}^{2+}, \mathrm{Cd}^{2+}, \mathrm{Mn}^{2+}$, $\mathrm{Cu}^{2+}$ apod.), vzácněji i $\mathrm{Cu}^{+}$nebo $\mathrm{Fe}^{3+}$ ve stejné koordinaci jako $B$; v pozici $X$ se $v$ trigonálně pyramidální koordinaci uplatňují $\mathrm{Sb}^{3+}, \mathrm{As}^{3+}, \mathrm{Bi}^{3+}$ a $\mathrm{Te}^{4+}$; v aniontových pozicích pak vystupují $\mathrm{S}^{2-}, \mathrm{Se}^{2-}$ ( $v$ tetraedrické koordinaci v pozici Y) a $\mathrm{S}^{2-}, \mathrm{Se}^{2-} \mathrm{a} \square$ v pozici $Z$ ve specifické oktaedrické koordinaci (Moëlo et al. 2008; Biagioni et al. 2020a). Recentně publikovaná nová klasifikace této skupiny (Biagioni et al. 2020a) přináší využití zastoupení dvojmocných prvků v $C$ pozici pro nomenklaturu jednotlivých minerálních druhů; pro nejčastější tetraedrit a tennantit jsou ale $v$ publikova- né klasifikaci jednoznačně definovány jen členy s převahu Fe a Zn (Biagioni et al. 2020a).

Dlouhodobý výzkum minerálů skupiny tetraedritu je v Národním muzeu zaměřen zejména na členy $s$ méně obvyklým chemickým složením (Velebil et al. 2016). Výzkum Hg-bohatých tetraedritů (Velebil, Losos 2008; Velebil 2014) vedl i k formální definici nového druhu tetraedritu -(Hg) (Biagioni et al. 2020b). Zjištěny byly i Bi-dominantní analogy tennantitu- $(\mathrm{Zn})$, ale velikost jejich agregátů dosud neumožnila zjistit strukturní data nezbytná pro formální prijjetí nového minerálního druhu (Velebil, Sejkora 2018). Podrobně byly studovány i hakity jako Se-dominantní členy této skupiny (Škácha et al. 2016, 2017) a definován pošepnýit jako nový druh $\mathrm{s}$ idealizovaným vzorcem $\left(\mathrm{Cu}_{3+x}^{+} \square_{3-x}\right)_{\Sigma 6}\left(\mathrm{Hg}^{2+}{ }_{4-x} \mathrm{Cu}^{+}{ }_{2+x}\right)_{\Sigma 6} \mathrm{Sb}_{4}\left(\mathrm{Se}_{12.5} \square_{0.5}\right)_{\Sigma 13}$ (Škácha et al. 2020).

$\mathrm{Mn}^{2+}$ bohaté tetraedrity (a tennantity) jsou známy již relativně dlouho. Basu et al. (1984) popsali Mn-bohatý tetraedrit s obsahem do 1.71 apfu z polymetalického ložiska Rajpura-Dariba v Indii; Dobbe (1992) analyzoval tetraedrit z Bergslagenu ve Švédsku, přičemž v jím studovaném vzorku dominoval $\mathrm{Mn}$ nad $\mathrm{Cd}$ a Fe. Damian, Damian (2003) uvádějí z lokality Gura Barza (v. od Bradu) tetraedrit o obsahu do 1.31 apfu Mn a z lokality Coranda-Hondol (cca 3 km zsz. od Săcărâmbu, obě ložiska v pohoří Muntii Metaliferi) tetraedrit o obsahu do 1.87 apfu Mn. Burkart-Baumann (1984) zjistil $\mathrm{Mn}^{2+}$ dominantní (až 1.53 apfu) tennantit v materiálu z ložiska Quiruvilca v Peru. Makovicky, Karup-Møller (1994) syntetizovali tetraedrit s obsahem až 1.91 apfu Mn; Mn-bohaté tetraedrity také připravili Suekuni et al. (2014); Chetty et al. (2015) syntetizovali tetraedrity s obsahy Mn do 2 apfu 
Tabulka 1 Přehled studovaných vzorků

\begin{tabular}{llll}
\hline č. vz. & inv. č. NM & lokalita & popis makrovzorku \\
\hline D110 & P1N 615 & Cavnic & až 1 cm krystaly a zrnité agregáty s křemenem; ex coll. J. Zeidler \\
D112 & P1N 10003 & Cavnic & celistvé agregáty v rodochrositu s křemenem; ex coll. F. Zippe \\
D113 & P1N 10010 & Cavnic & celistvý s chalkopyritem na křemeni s rodochrositem; ex coll. T. Lindacker \\
D114 & P1N 85960 & Cavnic & zrnité agregáty na rodochrositu s křemenem; ex coll. H. Reiff \\
D115 & P1N 85960 & Cavnic & zrnité agregáty na rodochrositu s křemenem; ex coll. H. Reiff \\
D116 & P1N 78174 & Botești & až 1.5 cm krystaly na žilovině s křemenem; ex coll. A. Kloos \\
D117 & P1N 100066 & Botești & až 2.5 cm krystaly na drúze krystalů křemene; ex coll. M. Richter \\
D118 & P1N 10018 & Săcărâmb & drobné krystaly s rodochrositem na křemeni; ex coll. J. Zeidler \\
\hline
\end{tabular}

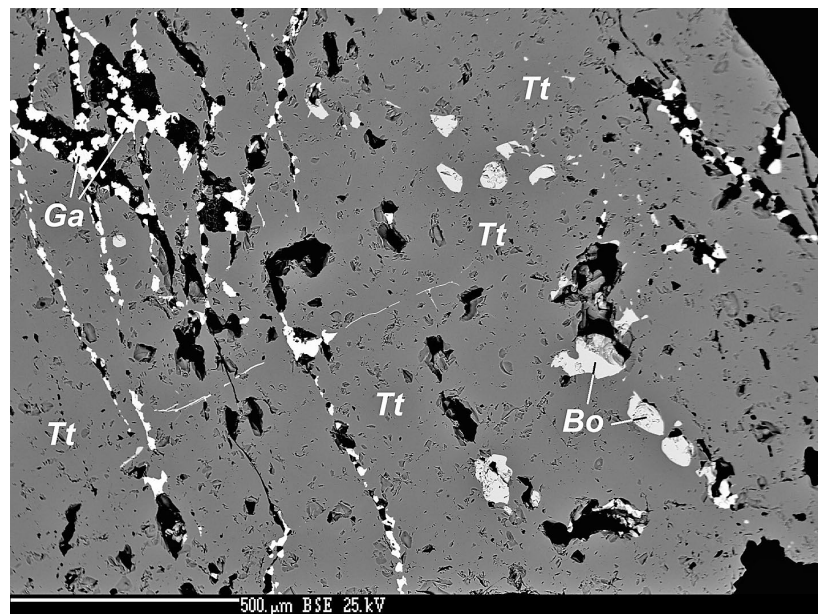

Obr. 1 Vzorek D110, tetraedrit-(Zn), Cavnic, Rumunsko (Národni muzeum P1N 615); masivní tetraedrit (Tt) s inkluzemi galenitu (Ga) a bournonitu (Bo). BSE foto Z. Dolníček.

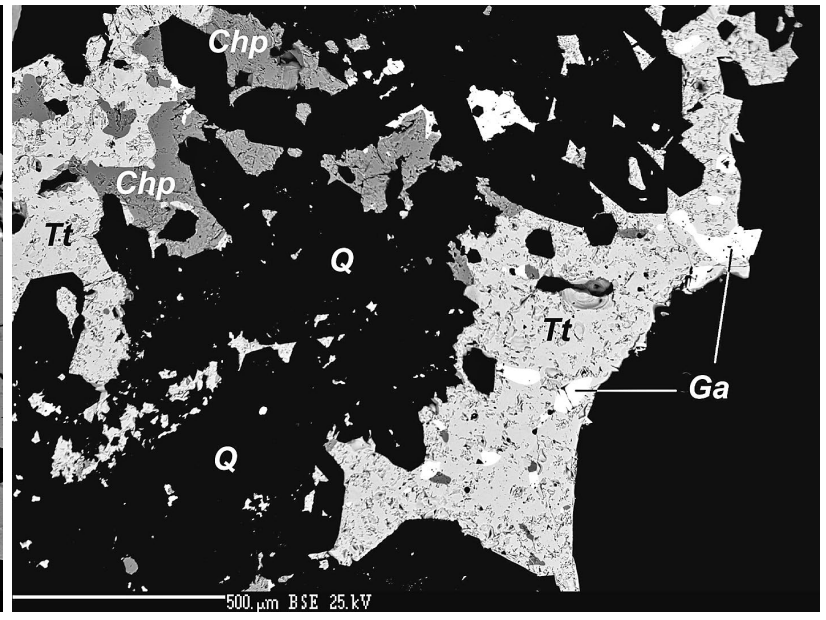

Obr. 2 Vzorek D113, tetraedrit-(Zn), Cavnic, Rumunsko (Národní muzeum P1N 10010); tetraedrit (Tt) v křemeni (Q) srůstá s chalkopyritem (Chp) a uzavírá galenit (Ga). BSE foto Z. Dolníček.

Tabulka 2 Chemické složení vzorku D110 (tetraedrit-(Zn), Cavnic, Rumunsko; NM P1N 615) v hm. \% a příslušné hodnoty apfu

\begin{tabular}{lrrrrrrrrrrr}
\hline & \multicolumn{1}{c}{1} & \multicolumn{1}{c}{4} & \multicolumn{1}{c}{3} & \multicolumn{1}{c}{5} & \multicolumn{1}{c}{6} & \multicolumn{1}{c}{7} & \multicolumn{1}{c}{8} & \multicolumn{1}{c}{9} & 10 & průměr \\
\hline $\mathrm{Ag}$ & 11.94 & 12.35 & 11.96 & 11.99 & 10.10 & 10.16 & 10.78 & 11.01 & 11.38 & 11.50 & 11.32 \\
$\mathrm{Cu}$ & 28.68 & 28.51 & 28.67 & 28.67 & 29.90 & 29.89 & 29.55 & 29.31 & 29.11 & 28.97 & 29.13 \\
$\mathrm{~Pb}$ & 0 & 0 & 0 & 0 & 0 & 0 & 0 & 0 & 0 & 0.15 & 0.02 \\
$\mathrm{Cd}$ & 0 & 0 & 0 & 0.07 & 0.05 & 0.06 & 0 & 0 & 0 & 0.07 & 0.03 \\
$\mathrm{Zn}$ & 4.31 & 4.62 & 4.75 & 5.29 & 6.50 & 7.00 & 5.91 & 5.52 & 5.75 & 5.87 & 5.55 \\
$\mathrm{Fe}$ & 2.48 & 2.23 & 2.01 & 1.59 & 0.64 & 0.17 & 1.11 & 1.37 & 1.29 & 1.15 & 1.40 \\
$\mathrm{Sn}$ & 0.07 & 0.13 & 0.06 & 0.09 & 0 & 0 & 0 & 0.06 & 0.07 & 0.06 & 0.05 \\
$\mathrm{Sb}$ & 28.22 & 28.47 & 28.60 & 28.48 & 28.80 & 28.83 & 28.54 & 28.53 & 28.60 & 28.59 & 28.57 \\
$\mathrm{As}$ & 0.21 & 0.06 & 0.09 & 0.06 & 0 & 0 & 0.06 & 0.11 & 0.08 & 0.03 & 0.07 \\
$\mathrm{~S}$ & 23.89 & 23.70 & 23.73 & 23.59 & 23.79 & 23.70 & 23.76 & 23.75 & 23.60 & 23.82 & 23.73 \\
\hline $\mathrm{Total}$ & 99.98 & 100.07 & 99.87 & 99.83 & 99.78 & 99.81 & 99.71 & 99.66 & 99.88 & 100.21 & 99.88 \\
\hline $\mathrm{apfu}$ & & & & & & & & & & & \\
$\mathrm{Ag}$ & 1.95 & 2.01 & 1.96 & 1.96 & 1.64 & 1.65 & 1.76 & 1.80 & 1.85 & 1.87 & 1.85 \\
$\mathrm{Cu}$ & 7.96 & 7.89 & 7.96 & 7.95 & 8.26 & 8.25 & 8.17 & 8.12 & 8.04 & 8.02 & 8.06 \\
$\mathrm{~Pb}$ & 0 & 0 & 0 & 0 & 0 & 0 & 0 & 0 & 0 & 0.01 & 0 \\
$\mathrm{Cd}$ & 0 & 0 & 0 & 0.01 & 0.01 & 0.01 & 0 & 0 & 0 & 0.01 & 0 \\
$\mathrm{Zn}$ & 1.16 & 1.24 & 1.28 & 1.43 & 1.74 & 1.88 & 1.59 & 1.49 & 1.54 & 1.58 & 1.49 \\
$\mathrm{Fe}$ & 0.78 & 0.70 & 0.63 & 0.50 & 0.20 & 0.05 & 0.35 & 0.43 & 0.41 & 0.36 & 0.44 \\
$\mathrm{Sn}$ & 0.01 & 0.02 & 0.01 & 0.01 & 0 & 0 & 0 & 0.01 & 0.01 & 0.01 & 0.01 \\
$\mathrm{Sb}$ & 4.09 & 4.11 & 4.14 & 4.12 & 4.15 & 4.15 & 4.12 & 4.13 & 4.12 & 4.13 & 4.13 \\
$\mathrm{As}$ & 0.05 & 0.01 & 0.02 & 0.01 & 0 & 0 & 0.01 & 0.03 & 0.02 & 0.01 & 0.02 \\
$\mathrm{~S}$ & 13.14 & 13.00 & 13.05 & 12.97 & 13.02 & 12.97 & 13.02 & 13.04 & 12.92 & 13.06 & 13.02 \\
\hline & & & & & & & & & &
\end{tabular}


a pro člen s 1.4 apfu Mn vyřešili krystalovou strukturu. Formální popis tetraedritu-(Mn) nebo tennantitu-(Mn) jako platného minerálního druhu však dosud chybí (Biagioni et al. 2020a). Obecně jsou ale obsahy Mn v minerálech skupiny tetraedritu vzácné a pohybují se nejvýše kolem meze detekce elektronové mikroanalýzy (Johnson et al. 1986; George et al. 2017).

$\checkmark$ této práci jsou uvedeny výsledky podrobného výzkumu chemického složení Mn-obsahujících tetraedritů z rumunských historických ložisek Cavnic, Botești a Săcărâmb na základě vzorků uložených v mineralogické sbírce Národního muzea v Praze.

\section{Metodika výzkumu}

Pro studium bylo odebráno osm zrn ze sedmi vzorků minerálů skupiny tetraedritu z rumunských lokalit uložených $v$ mineralogické sbírce Národního muzea (tab. 1). Nábrusy studovaných vzorků byly pro chemické analýzy připraveny standardním leštěním pomocí diamantové suspenze. Chemické složení bylo kvantitativně studováno pomocí elektronového mikroanalyzátoru Cameca SX100 (Národní muzeum, Praha). Na přístroji byly pořízeny snímky ve zpětně odražených elektronech (BSE), provedena identifikace jednotlivých fází pomocí energiově disperzních (EDS) spekter a kvantitativně měřeno chemické složení vybraných fází ve vinově disperzním (WDS) modu. Podmínky kvantitativních analýz byly následující: vlnově disperzní analýza, napětí $25 \mathrm{kV}$, proud $20 \mathrm{nA}$, průměr svazku $2 \mu \mathrm{m}$, standardy a použité analytické čáry: $\mathrm{CuFeS}_{2}(\mathrm{SK} \alpha, \mathrm{CuK \alpha}), \mathrm{Ag}(\mathrm{AgL} \alpha), \mathrm{Bi}_{2} \mathrm{Se}_{3}(\mathrm{BiM} \beta)$, CdTe (CdLa), Co (CoKa), Fes $(\mathrm{FeK \alpha}), \mathrm{HgTe}(\mathrm{HgL} \alpha)$, $\mathrm{NiAs}(\mathrm{AsL} \beta), \mathrm{Ni}(\mathrm{NiK \alpha}), \mathrm{PbS}(\mathrm{PbM \alpha}), \mathrm{PbSe}(\mathrm{SeL} \beta), \mathrm{Sb}_{2} \mathrm{~S}_{3}$ (SbLa), ZnS (ZnKa), Mn (MnKa), Au (AuMa), InAs (InL $\alpha)$, $\mathrm{PbTe}(\mathrm{TeL} \alpha), \mathrm{Sn}(\mathrm{SnL} \alpha), \mathrm{NaCl}(\mathrm{ClK} \alpha), \mathrm{Ge}(\mathrm{GeL} \alpha), \mathrm{GaAs}$ $(\mathrm{GaL} \alpha), \mathrm{Cr}(\mathrm{CrK \alpha}), \mathrm{BaSO}_{4}(\mathrm{BaL} \alpha)$, sanidin (KKa), fluorapatit (PKa). V tabulkách chemických analýz nejsou uvedeny prvky, jejichž obsahy byly pod detekčním limitem (cca 0.02 - 0.1 hm. \%; pro Hg okolo 0.65 hm. \%). Získaná data byla korigována za použití software PAP (Pouchou, Pichoir 1985). Celkem bylo provedeno 58 bodových analýz. Empirické vzorce tetraedritů byly přepočteny na sumu kationtů rovnou 16 apfu.

\section{Výsledky}

\section{Cavnic}

Žilné polymetalické ložisko olova, zinku a stříbra Cavnic se nachází asi $20 \mathrm{~km}$ v. od města Baia Mare v župě Maramureš na severu Rumunska. Těženo bylo nejpozději od 14. století až do roku 2008. Na žilách jsou mimo jiné přítomny minerály manganu (rodochrosit, kutnohorit, rodonit) a antimonit. Ložisko Cavnic je typovou lokalitou rodochrositu (Pauliš, Beneš 2005b).

Vzorek D110 je v BSE obraze homogenní tetraedrit s drobnými inkluzemi galenitu (určeno EDS analýzou) uspořádanými do zhruba rovnoběžných „vrstev“ a s víceméně izometrickými inkluzemi bournonitu (určeno WDS) velikosti do cca $150 \mu \mathrm{m}$ (obr. 1). Vzorek D110 je stříbrem bohatý tetraedrit-(Zn); průměr deseti bodových analýz (tab. 2) poskytl empirický vzorec $\left(\mathrm{Cu}_{4.15} \mathrm{Ag}_{1.85}\right)_{\Sigma 6.00}$ $\left[\mathrm{Cu}_{3.91}\left(\mathrm{Zn}_{1.49} \mathrm{Fe}_{0.44}\right)_{\Sigma 1.93}\right]_{\Sigma 5.84}\left(\mathrm{Sb}_{4.13} \mathrm{As}_{0.02}\right)_{\Sigma 4.15} \mathrm{~S}_{13.02}$. Všech deset analýz provedených ve dvou na sebe zhruba kolmých řadách např́č zrnem vykázalo také stopy Sn - průměrně $0.07(0.06-0.13) \mathrm{hm}$. \% . To odpovídá průměrné hodnotě 0.01 apfu Sn. Mangan vykazoval pouze hodnoty pod detekčním limitem.
Tabulka 3 Chemické složení vzorku D112 (tetraedrit -(Zn), Cavnic, Rumunsko; NM P1N 10003) v hm. \% a príslušné hodnoty apfu

\begin{tabular}{lrrrrr}
\hline & \multicolumn{1}{c}{2} & \multicolumn{1}{l}{3} & \multicolumn{1}{c}{4} & prùměr \\
\hline $\mathrm{Ag}$ & 4.80 & 4.85 & 5.08 & 5.07 & 4.95 \\
$\mathrm{Cu}$ & 34.23 & 34.27 & 34.08 & 34.10 & 34.17 \\
$\mathrm{~Pb}$ & 0.11 & 0 & 0 & 0 & 0.03 \\
$\mathrm{Cd}$ & 0.05 & 0 & 0.03 & 0.05 & 0.03 \\
$\mathrm{Zn}$ & 6.48 & 6.44 & 6.25 & 6.59 & 6.44 \\
$\mathrm{Fe}$ & 0.65 & 0.67 & 0.65 & 0.56 & 0.63 \\
$\mathrm{Mn}$ & 0.26 & 0.27 & 0.28 & 0.25 & 0.27 \\
$\mathrm{Sn}$ & 0 & 0 & 0.07 & 0.07 & 0.04 \\
$\mathrm{Sb}$ & 27.01 & 26.70 & 27.49 & 26.83 & 27.01 \\
$\mathrm{As}$ & 1.67 & 1.66 & 1.51 & 1.54 & 1.60 \\
$\mathrm{~S}$ & 24.64 & 24.77 & 24.63 & 25.37 & 24.85 \\
\hline $\mathrm{Total}$ & 99.90 & 99.63 & 100.07 & 100.43 & 100.02 \\
\hline $\mathrm{apfu}$ & & & & & \\
$\mathrm{Ag}$ & 0.75 & 0.76 & 0.80 & 0.80 & 0.78 \\
$\mathrm{Cu}$ & 9.13 & 9.17 & 9.10 & 9.13 & 9.13 \\
$\mathrm{~Pb}$ & 0.01 & 0 & 0 & 0 & 0 \\
$\mathrm{Cd}$ & 0.01 & 0 & 0 & 0.01 & 0 \\
$\mathrm{Zn}$ & 1.68 & 1.67 & 1.62 & 1.71 & 1.67 \\
$\mathrm{Fe}$ & 0.20 & 0.20 & 0.20 & 0.17 & 0.19 \\
$\mathrm{Mn}$ & 0.08 & 0.08 & 0.09 & 0.08 & 0.08 \\
$\mathrm{Sn}$ & 0 & 0 & 0.01 & 0.01 & 0.01 \\
$\mathrm{Sb}$ & 3.76 & 3.73 & 3.83 & 3.75 & 3.77 \\
$\mathrm{As}$ & 0.38 & 0.38 & 0.34 & 0.35 & 0.36 \\
$\mathrm{~S}$ & 13.03 & 13.13 & 13.04 & 13.45 & 13.16 \\
\hline
\end{tabular}

Tabulka 4 Chemické složení vzorku D113 (tetraedrit -(Zn), Cavnic, Rumunsko; NM P1N 10010) v hm. \% a přislušné hodnoty apfu

\begin{tabular}{lrrrrr}
\hline & \multicolumn{1}{c}{1} & \multicolumn{1}{c}{3} & \multicolumn{1}{c}{4} & průměr \\
\hline $\mathrm{Ag}$ & 9.99 & 11.66 & 10.92 & 10.36 & 10.73 \\
$\mathrm{Cu}$ & 30.33 & 29.23 & 29.70 & 30.23 & 29.87 \\
$\mathrm{Cd}$ & 0.12 & 0.12 & 0.09 & 0.10 & 0.11 \\
$\mathrm{Zn}$ & 6.35 & 6.28 & 6.37 & 6.47 & 6.37 \\
$\mathrm{Fe}$ & 0.71 & 0.68 & 0.66 & 0.73 & 0.70 \\
$\mathrm{Sn}$ & 0 & 0.07 & 0 & 0.08 & 0.04 \\
$\mathrm{Sb}$ & 27.06 & 27.46 & 27.01 & 26.66 & 27.05 \\
$\mathrm{As}$ & 1.34 & 0.79 & 1.06 & 1.48 & 1.17 \\
$\mathrm{~S}$ & 24.74 & 24.03 & 24.04 & 24.33 & 24.29 \\
\hline $\mathrm{Total}$ & 100.64 & 100.32 & 99.85 & 100.44 & 100.33 \\
\hline $\mathrm{apfu}$ & & & & & \\
$\mathrm{Ag}$ & 1.61 & 1.89 & 1.77 & 1.66 & 1.73 \\
$\mathrm{Cu}$ & 8.29 & 8.05 & 8.18 & 8.24 & 8.19 \\
$\mathrm{Cd}$ & 0.02 & 0.02 & 0.01 & 0.02 & 0.02 \\
$\mathrm{Zn}$ & 1.69 & 1.68 & 1.70 & 1.71 & 1.70 \\
$\mathrm{Fe}$ & 0.22 & 0.21 & 0.21 & 0.23 & 0.22 \\
$\mathrm{Sn}$ & 0 & 0.01 & 0 & 0.01 & 0.01 \\
$\mathrm{Sb}$ & 3.86 & 3.95 & 3.88 & 3.79 & 3.87 \\
$\mathrm{As}$ & 0.31 & 0.18 & 0.25 & 0.34 & 0.27 \\
$\mathrm{~S}$ & 13.41 & 13.12 & 13.12 & 13.14 & 13.19 \\
\hline
\end{tabular}


Ve vzorku D112 bylo analyzováno $0.8 \mathrm{~mm}$ velké v BSE obraze homogenní, nepravidelné zrno tetraedritu obklopené křemenem a spolu s ním uzavřené ve směsi dalších minerálů, kterými jsou podle EDS analýz rodonit jako převládající minerál a $v$ něm zarostlá zrna sfaleritu, chalkopyritu, galenitu a K-živce. Vzorek D112 je stříbrem nabohacený tetraedrit-(Zn); průměr čtyř bodových analýz (tab. 3) poskytl empirický vzorec $\left(\mathrm{Cu}_{5.22} \mathrm{Ag}_{0.78}\right)_{\Sigma 6.00}$ $\left[\mathrm{Cu}_{3.91}\left(\mathrm{Zn}_{1.67} \mathrm{Fe}_{0.19} \mathrm{Mn}_{0.08}\right)_{\Sigma 1.94}\right]_{\Sigma 5.85}\left(\mathrm{Sb}_{3.77} \mathrm{As}_{0.36}\right)_{\Sigma 4.13} \mathrm{~S}_{13.16}$. Všechny čtyři provedené analýzy vykázaly př́tomnost $0.25-0.28 \mathrm{hm}$. \% Mn ( průměrně 0.08 apfu) a také stopy $\mathrm{Pb}$ a Sn oscilující okolo detekčního limitu $(\mathrm{Pb}$ do $0.11 \mathrm{hm}$. $\%$; Sn do $0.07 \mathrm{hm}$. \%).

Ve vzorku D113 byl měřen 1.6 mm velký agregát tetraedritu, v BSE obraze homogenní, uzavřený v křemeni. Tetraedrit srůstá s podřizeným chalkopyritem a uzavírá ne-

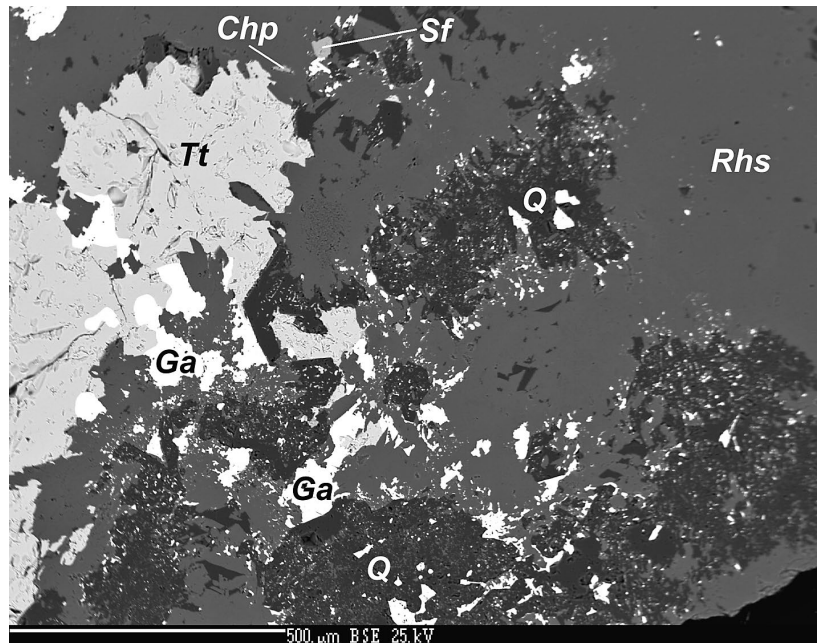

Obr. 3 Vzorek D114, tetraedrit-(Zn), Cavnic, Rumunsko (Národni muzeum P1N 85960); rodochrosit (Rhs) uzavírá tetraedrit $(T t)$, křemen $(Q)$, galenit $(\mathrm{Ga})$, chalkopyrit (Chp) a sfalerit (Sf). BSE foto Z. Dolníček.

Tabulka 5 Chemické složení vzorku D114 (tetraedrit -(Zn), Cavnic, Rumunsko; NM P1N 85960) v hm. \% a přislušné hodnoty apfu

\begin{tabular}{lrrrrr}
\hline & \multicolumn{1}{c}{1} & \multicolumn{1}{c}{3} & \multicolumn{1}{l}{4} & průměr \\
\hline $\mathrm{Ag}$ & 4.93 & 5.59 & 4.85 & 4.56 & 4.98 \\
$\mathrm{Cu}$ & 34.21 & 33.87 & 34.36 & 34.37 & 34.20 \\
$\mathrm{Zn}$ & 6.39 & 6.28 & 6.43 & 6.29 & 6.35 \\
$\mathrm{Fe}$ & 0.59 & 0.64 & 0.65 & 0.83 & 0.68 \\
$\mathrm{Mn}$ & 0.31 & 0.34 & 0.36 & 0.57 & 0.40 \\
$\mathrm{Sn}$ & 0.07 & 0 & 0.10 & 0.06 & 0.06 \\
$\mathrm{Sb}$ & 27.80 & 27.86 & 27.40 & 25.32 & 27.10 \\
$\mathrm{As}$ & 1.03 & 1.03 & 1.08 & 2.64 & 1.45 \\
$\mathrm{~S}$ & 24.65 & 24.52 & 24.73 & 24.93 & 24.71 \\
\hline $\mathrm{Total}$ & 99.98 & 100.13 & 99.96 & 99.57 & 99.93 \\
\hline $\mathrm{apfu}$ & & & & & \\
$\mathrm{Ag}$ & 0.78 & 0.88 & 0.76 & 0.71 & 0.78 \\
$\mathrm{Cu}$ & 9.16 & 9.06 & 9.18 & 9.13 & 9.13 \\
$\mathrm{Zn}$ & 1.66 & 1.63 & 1.67 & 1.62 & 1.65 \\
$\mathrm{Fe}$ & 0.18 & 0.19 & 0.20 & 0.25 & 0.21 \\
$\mathrm{Mn}$ & 0.10 & 0.11 & 0.11 & 0.18 & 0.12 \\
$\mathrm{Sn}$ & 0.01 & 0 & 0.01 & 0.01 & 0.01 \\
$\mathrm{Sb}$ & 3.88 & 3.89 & 3.82 & 3.51 & 3.78 \\
$\mathrm{As}$ & 0.23 & 0.23 & 0.24 & 0.59 & 0.33 \\
$\mathrm{~S}$ & 13.08 & 13.00 & 13.09 & 13.12 & 13.07 \\
\hline
\end{tabular}

pravidelná zrna galenitu (obr. 2) velikosti do $200 \mu \mathrm{m}$ (doprovodné minerály určeny EDS). Vzorek D113 je stř́brem bohatý tetraedrit-(Zn); průměr čtyř bodových analýz (tab. 4) poskytl empirický vzorec $\left(\mathrm{Cu}_{4.27} \mathrm{Ag}_{1.73}\right)_{\Sigma 6.00}$ $\left[\mathrm{Cu}_{3.92}\left(\mathrm{Zn}_{1.70} \mathrm{Fe}_{0.22} \mathrm{Cd}_{0.02}\right)_{\Sigma 1.94}\right]_{\Sigma 5.86}\left(\mathrm{Sb}_{3.87} \mathrm{As}_{0.27}\right)_{\Sigma 4.14} \mathrm{~S}_{13.19}$. Všechny čtyři analýzy provedené $v$ linii napříc středem tetraedritového zrna vykázaly také stopy $\mathrm{Sn}$ (do $0.08 \mathrm{hm}$. $\%)$. Mangan nebyl ve vzorku zjištěn.

Vzorek D114 je v BSE obraze homogenní tetraedrit (obr. 3) v těsné asociaci s podřizeným galenitem, uzavřený $v$ rodochrositu, který sám uzavírá domény křemene a zrna sfaleritu, chalkopyritu a galenitu (doprovodné minerály určeny EDS). Vzorek D114 je stříbrem a manganem nabohacený tetraedrit-(Zn) (obr. 4); průměr čtyř bodových analýz (tab. 5) poskytl empirický vzorec $\left(\mathrm{Cu}_{5.22} \mathrm{Ag}_{0.78}\right)_{\Sigma 6.00}$ $\left[\mathrm{Cu}_{3.91}\left(\mathrm{Zn}_{1.65} \mathrm{Fe}_{0.21} \mathrm{Mn}_{0.12}\right)_{\Sigma 1.98}\right]_{\Sigma 5.89}\left(\mathrm{Sb}_{3.78} \mathrm{As}_{0.33}\right)_{\Sigma 4.11} \mathrm{~S}_{13.07}$.

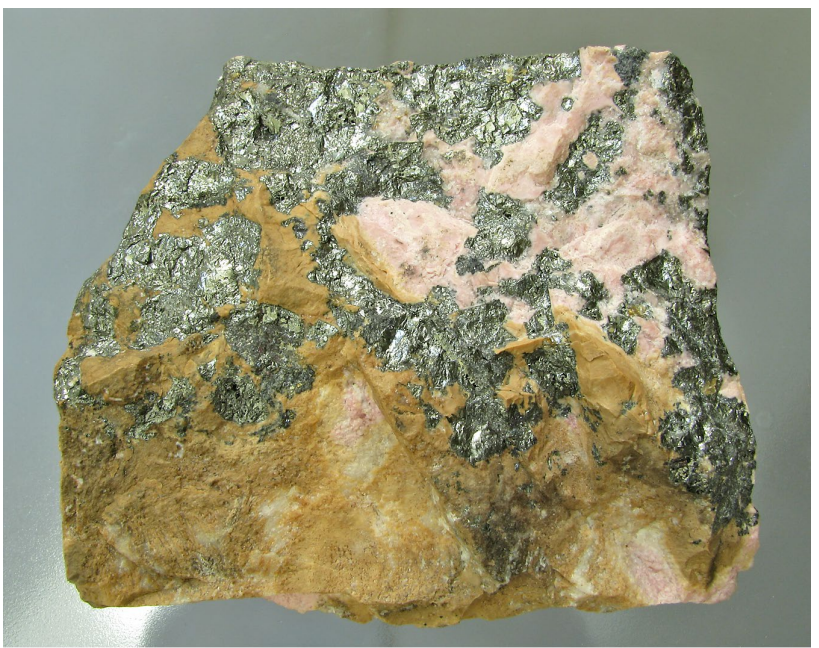

Obr. 4 Střibrem a manganem nabohacený tetraedrit-(Zn), Cavnic, Rumunsko, $8 \times 7 \mathrm{~cm}$, Národní muzeum P1N 85960 (vzorky D114 a D115). Foto D. Velebil.

Tabulka 6 Chemické složení vzorku D115 (tetraedrit -(Zn), Cavnic, Rumunsko; NM P1N 85960) v hm. \% a př́slušné hodnoty apfu

\begin{tabular}{lrrrrr}
\hline & \multicolumn{1}{c}{1} & \multicolumn{1}{c}{3} & \multicolumn{1}{c}{4} & průměr \\
\hline $\mathrm{Ag}$ & 4.79 & 4.82 & 4.71 & 4.80 & 4.78 \\
$\mathrm{Cu}$ & 34.32 & 34.40 & 34.34 & 34.31 & 34.34 \\
$\mathrm{Zn}$ & 6.37 & 6.41 & 6.32 & 6.33 & 6.36 \\
$\mathrm{Fe}$ & 0.52 & 0.53 & 0.53 & 0.51 & 0.52 \\
$\mathrm{Mn}$ & 0.40 & 0.42 & 0.42 & 0.45 & 0.42 \\
$\mathrm{Sn}$ & 0.08 & 0 & 0.07 & 0 & 0.04 \\
$\mathrm{Sb}$ & 27.39 & 27.50 & 27.42 & 27.79 & 27.53 \\
$\mathrm{As}$ & 1.25 & 1.20 & 1.26 & 1.20 & 1.23 \\
$\mathrm{~S}$ & 24.52 & 24.49 & 24.66 & 24.79 & 24.62 \\
\hline $\mathrm{Total}$ & 99.64 & 99.77 & 99.73 & 100.18 & 99.84 \\
\hline $\mathrm{apfu}$ & & & & & \\
$\mathrm{Ag}$ & 0.76 & 0.76 & 0.74 & 0.76 & 0.75 \\
$\mathrm{Cu}$ & 9.19 & 9.18 & 9.19 & 9.16 & 9.18 \\
$\mathrm{Zn}$ & 1.66 & 1.66 & 1.64 & 1.64 & 1.65 \\
$\mathrm{Fe}$ & 0.16 & 0.16 & 0.16 & 0.15 & 0.16 \\
$\mathrm{Mn}$ & 0.12 & 0.13 & 0.13 & 0.14 & 0.13 \\
$\mathrm{Sn}$ & 0.01 & 0 & 0.01 & 0 & 0.01 \\
$\mathrm{Sb}$ & 3.83 & 3.83 & 3.83 & 3.87 & 3.84 \\
$\mathrm{As}$ & 0.28 & 0.27 & 0.29 & 0.27 & 0.28 \\
$\mathrm{~S}$ & 13.01 & 12.96 & 13.08 & 13.12 & 13.04 \\
\hline
\end{tabular}


Všechny čtyři analýzy provedené v linii od středu k okraji dominantního zrna tetraedritu (velikosti $0.5 \mathrm{~mm}$ ) vykázaly také stopy Sn, a to průměrně $0.06(0.05-0.10) \mathrm{hm}$. \% ( průměrně 0.01 apfu $\mathrm{Sn})$. Mangan je přítomen v obsazích $0.10-0.17$ apfu.

Vzorek D 115 je masivní, v BSE obraze homogenní tetraedrit (obr. 5) s nehojnými inkluzemi galenitu, uzavírající domény tvořené směsí křemene, K-živce a rodonitu

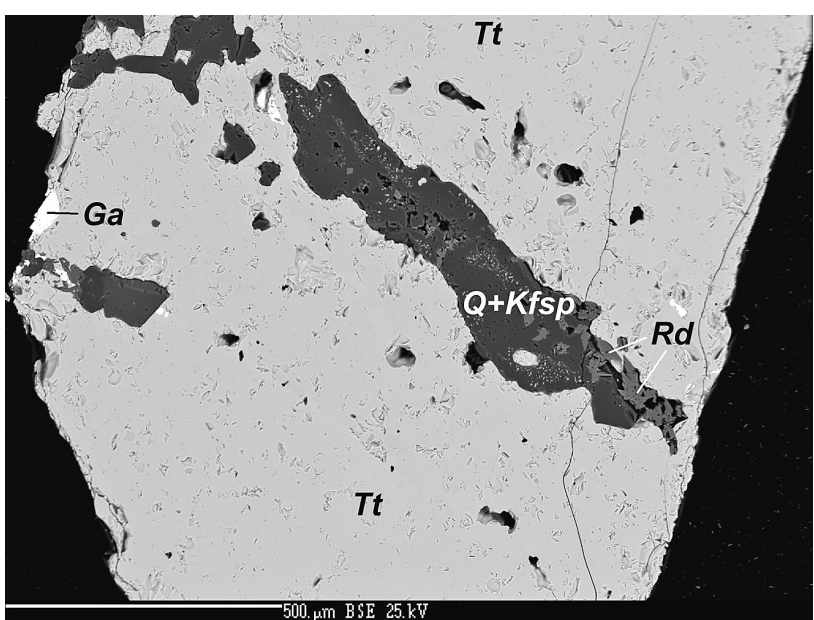

Obr. 5 Vzorek D115, tetraedrit-(Zn), Cavnic, Rumunsko (Národní muzeum P1N 85960); tetraedrit (Tt) uzavírá galenit $(\mathrm{Ga})$, kremen $(\mathrm{Q}), \mathrm{K}$-živec (Kfsp) a rodonit $(R d)$. BSE foto Z. Dolníček.

Obr. 6 Graf Ag vs. Cu (apfu) pro studované minerály skupiny tetraedritu z Rumunska.

Obr. 7 Graf Sb vs. As (apfu) pro studované minerály skupiny tetraedritu z Rumunska. (doprovodné minerály určeny EDS). Vzorek D115 je stř́brem a manganem nabohacený tetraedrit-(Zn) (obr. 4); průměr čtyř bodových analýz (tab. 6) poskytl empirický vzorec $\left(\mathrm{Cu}_{5.25} \mathrm{Ag}_{0.75}\right)_{\Sigma 6.00}\left[\mathrm{Cu}_{3.93}\left(\mathrm{Zn}_{1.65} \mathrm{Fe}_{0.16} \mathrm{Mn}_{0.13}\right)_{\Sigma 1.94}\right]_{\Sigma 5.87}$ $\left(\mathrm{Sb}_{384} \mathrm{As}_{028}\right)_{\Sigma 4.12} \mathrm{~S}_{1304}$. Všechny čtyři analýzy (tab. 6) provedené $v$ linii napríč hlavní masou tetraedritu vykázaly také stopy Sn do $0.08 \mathrm{hm}$. \%. Všechny čtyři analýzy také vykázaly téměř shodný obsah $\mathrm{Mn} v$ rozsahu 0.12 až 0.14 apfu.
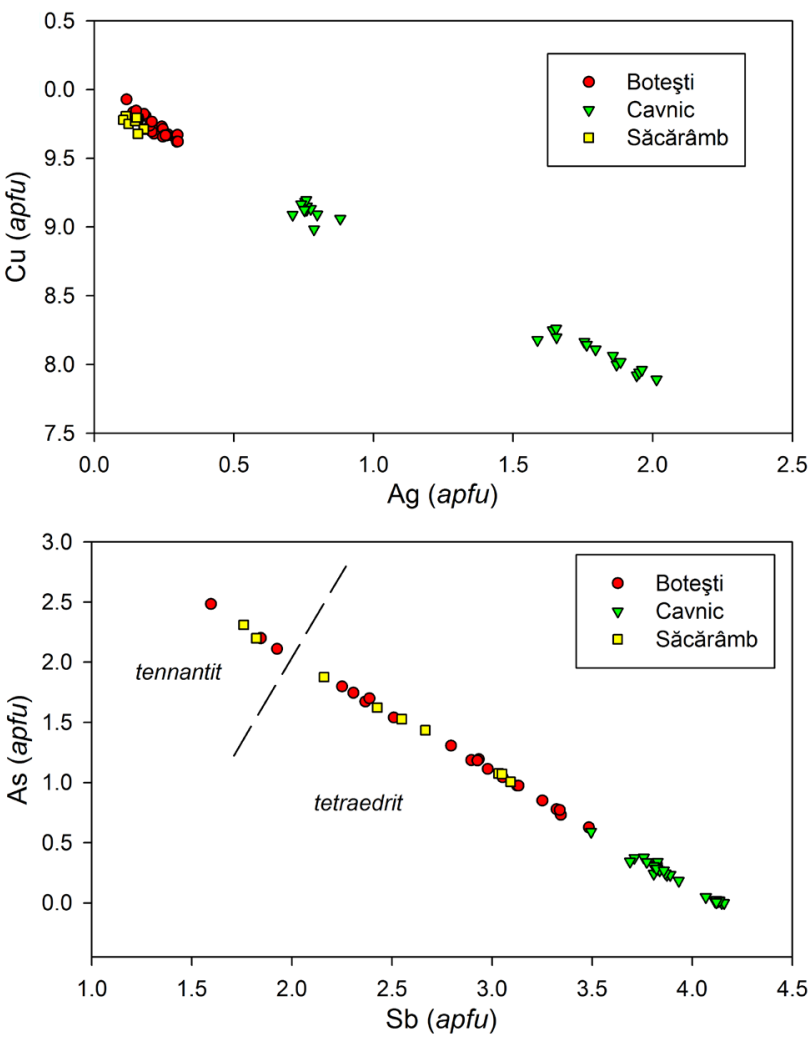

Tabulka 7 Chemické složení vzorku D116 (tetraedrit-(Zn), Botești, Rumunsko; NM P1N 78174) v hm. \% a příslušné hodnoty apfu

\begin{tabular}{lrrrrrrrrrrrrr}
\hline & 1 & 2 & 3 & 4 & 5 & 6 & 7 & 8 & 9 & 10 & 11 & 12 & průměr \\
\hline $\mathrm{Ag}$ & 1.42 & 1.07 & 1.37 & 1.36 & 1.66 & 1.34 & 1.61 & 1.96 & 1.38 & 1.03 & 1.69 & 1.68 & 1.46 \\
$\mathrm{Cu}$ & 37.84 & 38.93 & 37.80 & 37.67 & 37.55 & 38.62 & 37.28 & 37.09 & 38.52 & 39.68 & 37.20 & 37.46 & 37.97 \\
$\mathrm{~Pb}$ & 0 & 0 & 0 & 0 & 0 & 0 & 0 & 0.14 & 0 & 0 & 0 & 0 & 0.01 \\
$\mathrm{Cd}$ & 0 & 0 & 0 & 0.03 & 0 & 0 & 0 & 0 & 0 & 0.03 & 0 & 0 & 0.01 \\
$\mathrm{Zn}$ & 6.75 & 6.60 & 6.56 & 6.84 & 6.66 & 6.40 & 6.47 & 6.14 & 6.15 & 6.06 & 6.27 & 6.44 & 6.45 \\
$\mathrm{Fe}$ & 0.53 & 0.65 & 0.54 & 0.55 & 0.58 & 0.55 & 0.43 & 0.38 & 0.49 & 0.57 & 0.37 & 0.44 & 0.51 \\
$\mathrm{Mn}$ & 0.39 & 0.45 & 0.52 & 0.27 & 0.41 & 0.66 & 0.63 & 0.84 & 0.92 & 0.92 & 0.83 & 0.62 & 0.62 \\
$\mathrm{Sn}$ & 0.06 & 0.07 & 0 & 0 & 0.06 & 0 & 0.06 & 0.08 & 0 & 0.05 & 0.06 & 0 & 0.04 \\
$\mathrm{Sb}$ & 22.31 & 18.03 & 21.57 & 21.84 & 21.78 & 18.14 & 24.05 & 24.70 & 18.96 & 14.87 & 24.62 & 23.25 & 21.18 \\
$\mathrm{As}$ & 5.13 & 7.84 & 5.44 & 5.47 & 5.41 & 7.95 & 3.87 & 3.32 & 7.16 & 10.03 & 3.50 & 4.45 & 5.80 \\
$\mathrm{~S}$ & 25.77 & 26.23 & 25.58 & 25.52 & 25.49 & 26.14 & 25.41 & 25.42 & 25.97 & 26.57 & 25.28 & 25.51 & 25.75 \\
\hline $\mathrm{Total}$ & 100.20 & 99.87 & 99.38 & 99.55 & 99.60 & 99.80 & 99.81 & 100.10 & 99.55 & 99.81 & 99.82 & 99.85 & 99.80 \\
\hline $\mathrm{apfu}$ & & & & & & & & & & & & & \\
$\mathrm{Ag}$ & 0.21 & 0.16 & 0.21 & 0.21 & 0.25 & 0.20 & 0.25 & 0.30 & 0.21 & 0.15 & 0.26 & 0.26 & 0.22 \\
$\mathrm{Cu}$ & 9.72 & 9.84 & 9.74 & 9.70 & 9.67 & 9.77 & 9.68 & 9.66 & 9.80 & 9.89 & 9.68 & 9.69 & 9.74 \\
$\mathrm{~Pb}$ & 0 & 0 & 0 & 0 & 0 & 0 & 0 & 0.01 & 0 & 0 & 0 & 0 & 0 \\
$\mathrm{Cd}$ & 0 & 0 & 0 & 0 & 0 & 0 & 0 & 0 & 0 & 0 & 0 & 0 & 0 \\
$\mathrm{Zn}$ & 1.68 & 1.62 & 1.64 & 1.71 & 1.67 & 1.57 & 1.63 & 1.55 & 1.52 & 1.47 & 1.58 & 1.62 & 1.61 \\
$\mathrm{Fe}$ & 0.15 & 0.19 & 0.16 & 0.16 & 0.17 & 0.16 & 0.13 & 0.11 & 0.14 & 0.16 & 0.11 & 0.13 & 0.15 \\
$\mathrm{Mn}$ & 0.12 & 0.13 & 0.16 & 0.08 & 0.12 & 0.19 & 0.19 & 0.25 & 0.27 & 0.27 & 0.25 & 0.19 & 0.18 \\
$\mathrm{Sn}$ & 0.01 & 0.01 & 0 & 0 & 0.01 & 0 & 0.01 & 0.01 & 0 & 0.01 & 0.01 & 0 & 0.01 \\
$\mathrm{Sb}$ & 2.99 & 2.38 & 2.90 & 2.94 & 2.93 & 2.40 & 3.26 & 3.36 & 2.52 & 1.93 & 3.34 & 3.14 & 2.84 \\
$\mathrm{As}$ & 1.12 & 1.68 & 1.19 & 1.20 & 1.18 & 1.71 & 0.85 & 0.73 & 1.54 & 2.12 & 0.77 & 0.98 & 1.26 \\
$\mathrm{~S}$ & 13.11 & 13.13 & 13.07 & 13.03 & 13.01 & 13.11 & 13.08 & 13.13 & 13.09 & 13.12 & 13.03 & 13.08 & 13.08 \\
\hline & & & & & & & & & & & &
\end{tabular}


Souhrnně je po chemické stránce tetraedrit-(Zn) z ložiska Cavnic dvou typů - prvním je relativně Ag-bohatší tetraedrit (obr. 6) s obsahy Ag $1.61-2.01$ apfu a s obsahy Mn pod detekčním limitem (vzorky D110 a D113); druhým typem je tetraedrit s obsahy $\mathrm{Ag}$ jen $0.71-0.88$ apfu a zjištěnými obsahy $\mathrm{Mn}$ v rozmezí 0.08 - 0.18 apfu (vzorky D112, D114 a D115).

\section{Botești (Boteș)}

Historické ložisko zlata Botești (ve starých publikacích a sbírkách minerálů častěji jako Boteș či důl Botesbánya v oblasti Bucium) se nachází asi $10 \mathrm{~km} \mathrm{sz.} \mathrm{od} \mathrm{města} \mathrm{Zlat-}$ na, v župě Alba, v pohoří Muntii Metaliferi ve střední části Rumunska. Na ložisku jsou přitomny křemen, kalcit, sfalerit, tetraedrit, hessit, chlorargyrit a zlato (Huber, Huber 1983; Pauliš, Beneš 2005a).

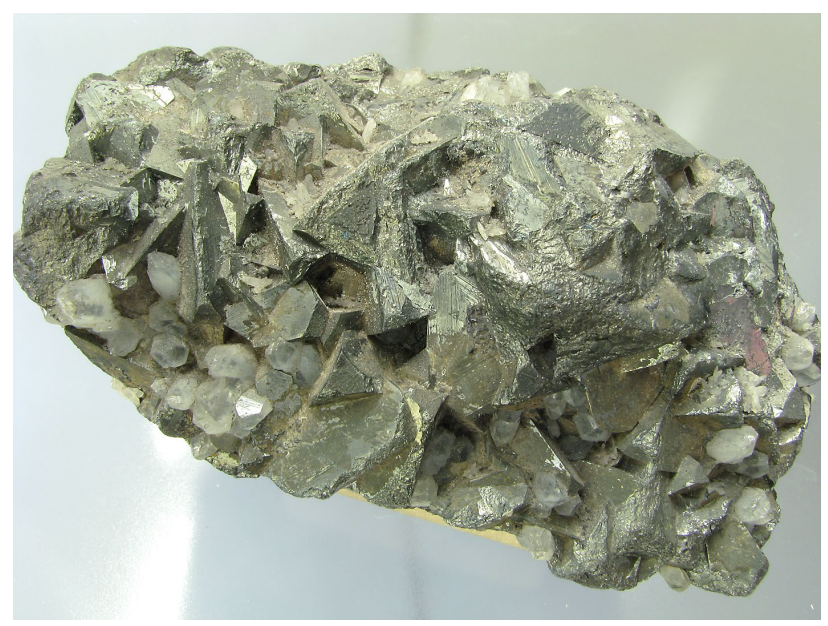

Obr. 8 Manganem a arsenem nabohacený tetraedrit-(Zn), Botești, Rumunsko, $10 \times 8 \mathrm{~cm}$, Národní muzeum P1N 78174 (vzorek D116). Foto D. Velebil.
Vzorek D116 je masivní, v BSE obraze zonální tetraedrit, príčemž tato zonálnost odráží variace v obsahu Sb/ As (Sb 1.93 - 3.36 apfu; As 0.73 - 2.12 apfu; jedna bodová analýza odpovídá již tennantitu - obr. 7). Tetraedrit obsahuje nehojné drobné inkluze hessitu velikosti do $50 \mu \mathrm{m}$ identifikovaného pomocí WDS analýz. V malé míře je v tetraedritu uzavírán také galenit, chalkopyrit a sfalerit (EDS). Vzorek D116 je manganem a arsenem nabohacený tetraedrit-(Zn) (obr. 8); průměr dvanácti bodových analýz poskytl empirický vzorec $\left(\mathrm{Cu}_{5.77} \mathrm{Ag}_{0.22}\right)_{\Sigma 6.00}\left[\mathrm{Cu}_{3.97}\left(\mathrm{Zn}_{1.61}\right.\right.$ $\left.\left.\mathrm{Mn}_{0.18} \mathrm{Fe}_{0.15}\right)_{\Sigma 1.94}\right]_{\Sigma 5.91}\left(\mathrm{Sb}_{2.84} \mathrm{As}_{1.26}\right)_{\Sigma 4.10} \mathrm{~S}_{13.08}$. Téméř všechny analýzy (tab. 7), provedené jednak $\vee$ místech $\vee$ blízkosti zrn hessitu a jednak např́č nejvýrazněji zonální částí vzorku, vykázaly také stopy $\mathrm{Pb}$ a $\mathrm{Sn}$ (Pb do $0.14 \mathrm{hm}$. \%; Sn do 0.08 hm. \%). Mangan byl zjištěn ve všech bodových

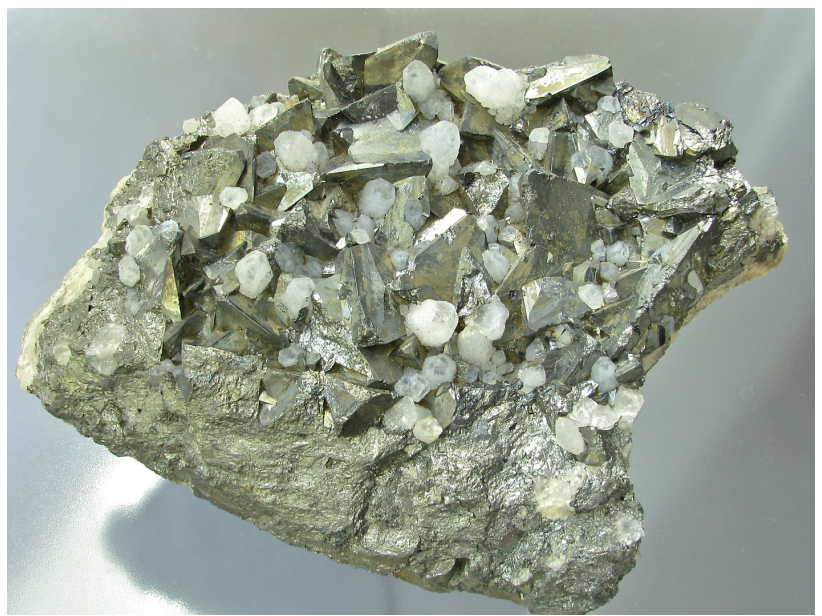

Obr. 9 Manganem a arsenem nabohacený tetraedrit-(Zn), Botești, Rumunsko, $15 \times 10 \mathrm{~cm}$, Národní muzeum P1N 100066 (vzorek D117). Foto D. Velebil.

Tabulka 8 Chemické složení vzorku D117 (tetraedrit-(Zn), Botești, Rumunsko; NM P1N 100066) v hm. \% a př́slušné hodnoty apfu

\begin{tabular}{|c|c|c|c|c|c|c|c|c|c|c|c|c|}
\hline & 1 & 2 & 3 & 4 & 5 & 6 & 7 & 8 & 9 & 10 & 11 & průměr \\
\hline $\mathrm{Ag}$ & 0.80 & 1.25 & 0.96 & 1.20 & 1.61 & 1.64 & 1.62 & 1.73 & 1.86 & 1.92 & 1.91 & 1.50 \\
\hline $\mathrm{Cu}$ & 40.37 & 39.14 & 39.78 & 39.00 & 38.22 & 37.49 & 37.70 & 37.28 & 37.02 & 36.67 & 36.58 & 38.11 \\
\hline $\mathrm{Pb}$ & 0.13 & 0 & 0 & 0.10 & 0 & 0 & 0 & 0 & 0.11 & 0 & 0 & 0.03 \\
\hline $\mathrm{Zn}$ & 5.56 & 5.67 & 5.62 & 5.62 & 5.71 & 5.64 & 5.57 & 5.58 & 5.73 & 5.98 & 6.29 & 5.72 \\
\hline $\mathrm{Fe}$ & 0.58 & 0.48 & 0.55 & 0.47 & 0.44 & 0.44 & 0.47 & 0.44 & 0.51 & 0.53 & 0.46 & 0.49 \\
\hline $\mathrm{Mn}$ & 1.30 & 1.37 & 1.41 & 1.43 & 1.42 & 1.39 & 1.30 & 1.33 & 1.19 & 0.90 & 0.69 & 1.25 \\
\hline Sn & 0 & 0 & 0 & 0 & 0.06 & 0 & 0 & 0 & 0.07 & 0.06 & 0.07 & 0.02 \\
\hline $\mathrm{Sb}$ & 12.43 & 17.21 & 14.29 & 17.55 & 21.03 & 23.24 & 22.70 & 24.53 & 25.59 & 27.78 & 27.87 & 21.29 \\
\hline As & 11.91 & 8.46 & 10.49 & 8.17 & 6.05 & 4.45 & 4.78 & 3.54 & 2.83 & 1.43 & 1.30 & 5.76 \\
\hline $\mathrm{Te}$ & 0.39 & 0 & 0.14 & 0 & 0 & 0 & 0 & 0 & 0 & 0 & 0 & 0.05 \\
\hline$S$ & 26.58 & 26.27 & 26.63 & 26.07 & 25.68 & 25.52 & 25.51 & 25.33 & 25.08 & 24.71 & 24.95 & 25.67 \\
\hline Total & 100.10 & 99.85 & 99.87 & 99.61 & 100.22 & 99.81 & 99.65 & 99.76 & 99.99 & 99.98 & 100.12 & 99.89 \\
\hline \multicolumn{13}{|l|}{$\overline{a p f u}$} \\
\hline $\mathrm{Ag}$ & 0.12 & 0.19 & 0.14 & 0.18 & 0.24 & 0.25 & 0.25 & 0.26 & 0.29 & 0.30 & 0.30 & 0.23 \\
\hline $\mathrm{Cu}$ & 9.90 & 9.84 & 9.87 & 9.83 & 9.71 & 9.68 & 9.73 & 9.69 & 9.64 & 9.62 & 9.62 & 9.74 \\
\hline $\mathrm{Pb}$ & 0.01 & 0 & 0 & 0.01 & 0 & 0 & 0 & 0 & 0.01 & 0 & 0 & 0 \\
\hline $\mathrm{Zn}$ & 1.32 & 1.38 & 1.35 & 1.38 & 1.41 & 1.42 & 1.40 & 1.41 & 1.45 & 1.52 & 1.61 & 1.42 \\
\hline $\mathrm{Fe}$ & 0.16 & 0.14 & 0.16 & 0.13 & 0.13 & 0.13 & 0.14 & 0.13 & 0.15 & 0.16 & 0.14 & 0.14 \\
\hline $\mathrm{Mn}$ & 0.37 & 0.40 & 0.40 & 0.42 & 0.42 & 0.42 & 0.39 & 0.40 & 0.36 & 0.27 & 0.21 & 0.37 \\
\hline Sn & 0 & 0 & 0 & 0 & 0.01 & 0 & 0 & 0 & 0.01 & 0.01 & 0.01 & 0.01 \\
\hline $\mathrm{Sb}$ & 1.59 & 2.26 & 1.85 & 2.31 & 2.79 & 3.13 & 3.06 & 3.33 & 3.48 & 3.80 & 3.83 & 2.86 \\
\hline As & 2.48 & 1.80 & 2.21 & 1.75 & 1.30 & 0.97 & 1.05 & 0.78 & 0.62 & 0.32 & 0.29 & 1.23 \\
\hline $\mathrm{Te}$ & 0.05 & 0 & 0.02 & 0 & 0 & 0 & 0 & 0 & 0 & 0 & 0 & 0.01 \\
\hline $\mathrm{S}$ & 12.92 & 13.08 & 13.09 & 13.02 & 12.93 & 13.06 & 13.05 & 13.05 & 12.94 & 12.84 & 13.01 & 13.00 \\
\hline
\end{tabular}


analýzách v rozsahu od 0.08 do 0.27 apfu. Žádná z analýz překvapivě nezachytila ani stopy telluru.

Vzorek D 117 je masivní, v BSE obraze zonální tetraedrit, srostlý $s$ galenitem (EDS). Pět bodových WDS analýz bylo provedeno $v$ linii napríć viditelnou zonalitou, dalších šest v nejsvětlejší části vzorku. Vzorek D117 je manganem a arsenem nabohacený tetraedrit-(Zn) (obr. 9); průměr jedenácti bodových analýz (tab. 8) poskytl empirický vzorec $\left(\mathrm{Cu}_{5.77} \mathrm{Ag}_{0.23}\right)_{\Sigma 6.00}\left[\mathrm{Cu}_{3.97}\left(\mathrm{Zn}_{1.42} \mathrm{Mn}_{0.37}\right.\right.$ $\left.\left.\mathrm{Fe}_{0.14}\right)_{\Sigma 1.95}\right]_{\Sigma 5.90}\left(\mathrm{Sb}_{2.86} \mathrm{As}_{1.23}\right)_{\Sigma 4.09} \mathrm{~S}_{13.00}$. Viditelně zonální část odráží variace v obsahu Sb/As (1.59 - 2.79 apfu Sb; dvě bodové analýzy odpovídají již tennantitu - obr. 7) a světlá část vykazuje relativně vyšší obsahy Sb (3.06 - $3.83 a p f u)$ vůči As. Téměř všechny provedené analýzy vykázaly stopy Sn (do 0.07 hm. \%). Mangan byl zjištěn ve všech bodových analýzách v rozsahu od 0.21 do 0.42 apfu. Tellur byl lokálně zachycen v obsazích do 0.05 apfu.

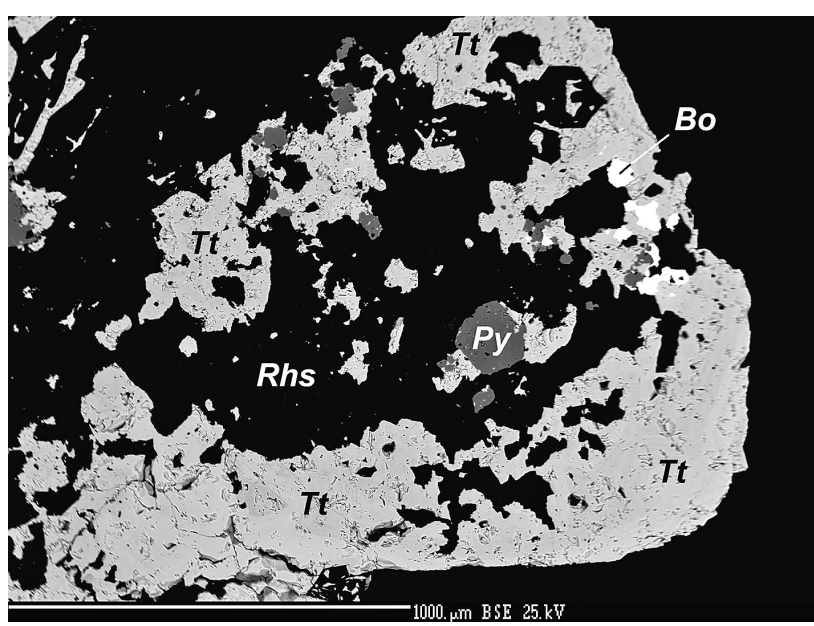

Obr. 10 Vzorek D118, tetraedrit-(Zn), Săcărâmb, Rumunsko (Národní muzeum P1N 10018); tetraedrit (Tt) $v$ asociaci $s$ rodochrositem (Rhs), bournonitem (Bo) srůstajícím $s$ galenitem a pyritem (Py). BSE foto Z. Dolníček.

\section{Săcărâmb}

Historické ložisko zlata a telluru Săcărâmb se nachází asi 15 km sv. od města Deva, v župě Hunedoara, v pohoří Muntii Metaliferi, cca $25 \mathrm{~km}$ jjz. od Botești. Na mineralogicky pestrém ložisku je typicky prítomen mimo jiné alabandin, bournonit, sfalerit, tetraedrit či rodochrosit; lokalita je známá historickými nálezy nagyagitu, hessitu a sylvanitu (Pauliš, Beneš 2005a).

Vzorek D118 je v BSE obraze (obr. 10) zonální tetraedrit zarostlý $v$ rodochrositu, $v$ těsné asociaci s bournonitem, galenitem a pyritem (doprovodné minerály určeny EDS). Vzorek D118 je manganem a arsenem bohatý tetraedrit-(Zn) (obr. 11); průměr devíti bodových analýz (tab. 9) poskytl empirický vzorec $\left(\mathrm{Cu}_{5.85} \mathrm{Ag}_{0.15}\right)_{\Sigma 6.00}$ $\left[\mathrm{Cu}_{3.96}\left(\mathrm{Zn}_{1.27} \mathrm{Mn}_{0.51} \mathrm{Fe}_{0.16}\right)_{\Sigma 1.94}\right]_{\Sigma 5.90}\left(\mathrm{Sb}_{2.52} \mathrm{As}_{1.58}\right)_{\Sigma 4.10} \mathrm{~S}_{13.15}$. $\checkmark$ BSE obraze světlé zóny $v$ tetraedritu se vyznačují vyš-

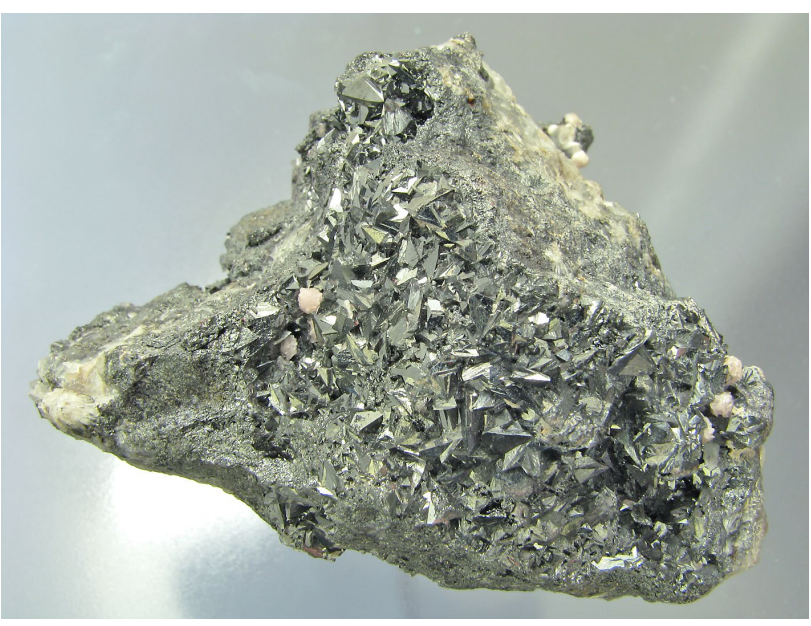

Obr. 11 Manganem a arsenem bohatý tetraedrit-(Zn), Săcărâmb, Rumunsko, $6 \times 6 \mathrm{~cm}$, Národní muzeum P1N 10018 (vzorek D118). Foto D. Velebil.

Tabulka 9 Chemické složení vzorku D118 (tetraedrit-(Zn), Săcărâmb, Rumunsko; NM P1N 10018) v hm. \% a príslušné hodnoty apfu

\begin{tabular}{|c|c|c|c|c|c|c|c|c|c|c|}
\hline & 1 & 2 & 3 & 4 & 5 & 6 & 7 & 8 & 9 & průměr \\
\hline $\mathrm{Ag}$ & 0.78 & 0.72 & 0.84 & 1.05 & 1.18 & 0.99 & 1.19 & 1.03 & 1.04 & 0.98 \\
\hline $\mathrm{Cu}$ & 39.69 & 39.81 & 39.18 & 38.30 & 37.98 & 38.80 & 38.29 & 39.01 & 37.81 & 38.76 \\
\hline $\mathrm{Pb}$ & 0 & 0.10 & 0 & 0 & 0 & 0 & 0 & 0 & 0 & 0.01 \\
\hline $\mathrm{Zn}$ & 5.66 & 5.39 & 5.40 & 5.86 & 5.87 & 5.16 & 3.69 & 3.52 & 5.78 & 5.15 \\
\hline $\mathrm{Fe}$ & 0.39 & 0.45 & 0.40 & 0.19 & 0.17 & 0.97 & 1.60 & 0.82 & 0.16 & 0.57 \\
\hline $\mathrm{Mn}$ & 1.64 & 1.81 & 1.83 & 1.43 & 1.45 & 1.48 & 1.87 & 2.86 & 1.44 & 1.76 \\
\hline Sn & 0 & 0 & 0 & 0.08 & 0.08 & 0 & 0.08 & 0.09 & 0 & 0.04 \\
\hline $\mathrm{Sb}$ & 14.13 & 13.72 & 16.64 & 22.74 & 22.86 & 19.39 & 20.14 & 18.51 & 23.15 & 19.03 \\
\hline As & 10.50 & 11.09 & 8.89 & 4.96 & 4.94 & 7.15 & 6.67 & 7.62 & 4.63 & 7.38 \\
\hline$S$ & 26.79 & 26.93 & 26.65 & 25.68 & 25.75 & 26.12 & 26.01 & 26.26 & 25.94 & 26.24 \\
\hline Total & 99.58 & 100.02 & 99.83 & 100.29 & 100.28 & 100.06 & 99.54 & 99.72 & 99.95 & 99.92 \\
\hline \multicolumn{11}{|l|}{ apfu } \\
\hline $\mathrm{Ag}$ & 0.11 & 0.10 & 0.12 & 0.16 & 0.18 & 0.15 & 0.18 & 0.15 & 0.16 & 0.15 \\
\hline $\mathrm{Cu}$ & 9.88 & 9.85 & 9.84 & 9.79 & 9.74 & 9.79 & 9.76 & 9.84 & 9.77 & 9.81 \\
\hline $\mathrm{Pb}$ & 0 & 0.01 & 0 & 0 & 0 & 0 & 0 & 0 & 0 & 0 \\
\hline $\mathrm{Zn}$ & 1.37 & 1.30 & 1.32 & 1.46 & 1.46 & 1.27 & 0.91 & 0.86 & 1.45 & 1.27 \\
\hline $\mathrm{Fe}$ & 0.11 & 0.13 & 0.11 & 0.06 & 0.05 & 0.28 & 0.46 & 0.24 & 0.05 & 0.16 \\
\hline $\mathrm{Mn}$ & 0.47 & 0.52 & 0.53 & 0.42 & 0.43 & 0.43 & 0.55 & 0.83 & 0.43 & 0.51 \\
\hline Sn & 0 & 0 & 0 & 0.01 & 0.01 & 0 & 0.01 & 0.01 & 0 & 0 \\
\hline $\mathrm{Sb}$ & 1.84 & 1.77 & 2.18 & 3.03 & 3.06 & 2.55 & 2.68 & 2.44 & 3.12 & 2.52 \\
\hline As & 2.22 & 2.33 & 1.89 & 1.08 & 1.07 & 1.53 & 1.44 & 1.63 & 1.02 & 1.58 \\
\hline$S$ & 13.22 & 13.20 & 13.26 & 13.01 & 13.08 & 13.06 & 13.14 & 13.12 & 13.29 & 13.15 \\
\hline
\end{tabular}



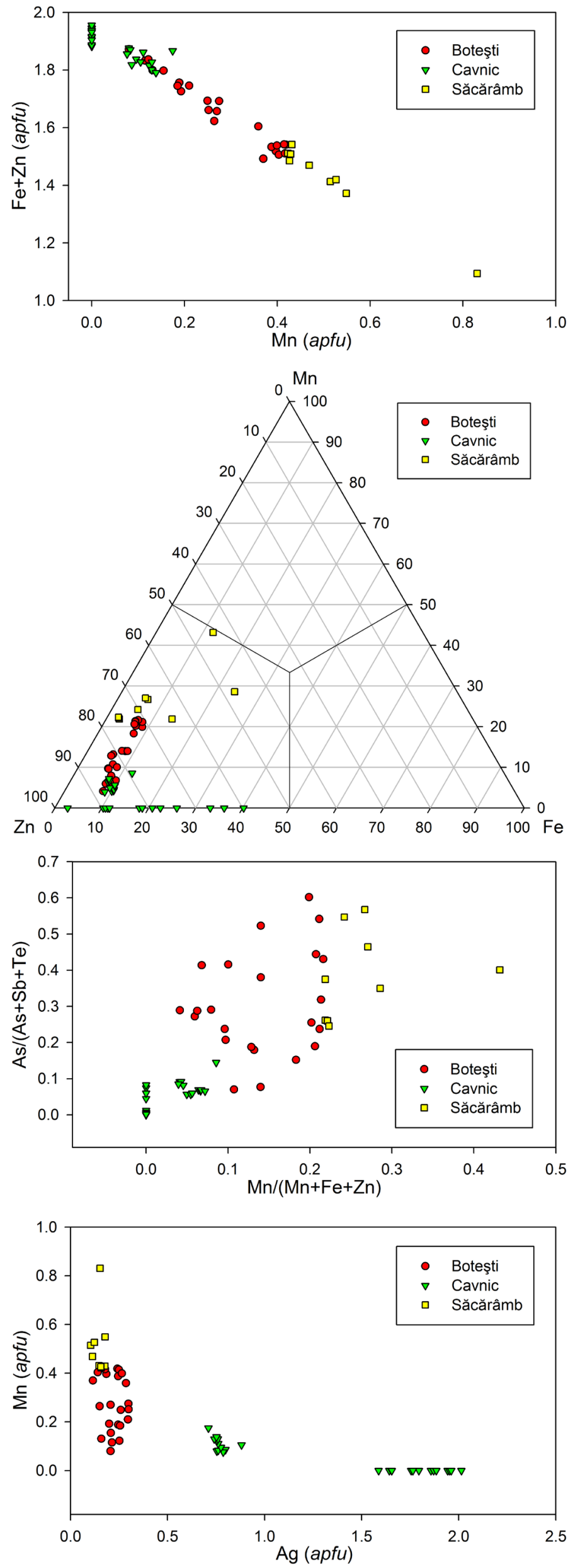

ším poměrem Sb/As (3.03 - 3.12 apfu Sb), tmavé zóny obsahují 1.77 - 2.68 apfu Sb (dvě bodové analýzy odpovídají již tennantitu - obr. 7). Téměř všechny analýzy, provedené $v$ různých částech světlejších i tmavších zón, vykázaly stopy Sn (do 0.09 hm. \%). Mangan byl zjištěn ve všech bodových analýzách v rozsahu od 0.42 do 0.83 apfu.

\section{Diskuse a závěr}

Mangan byl ve významnějším množství zjištěn $v$ šesti z celkem osmi studovaných vzorků (dva vzorky z Cavnicu Mn v podstatě neobsahovaly, ostatní tři ano). Nejvyšší zjištěný obsah Mn ve vzorcích z ložiska Cavnic byl 0.18 apfu. Manganem relativně bohatší jsou dva vzorky tetraedritu z lokality Botești (až 0.42 apfu); manganem nejbohatší je vzorek z lokality Săcărâmb (až 0.83 apfu). Tato zjištění zhruba odpovídají starším údajům o obsazích Mn v tetraedritech z lokalit Botești a Săcărâmb (Damian, Damian 2003). Pro lokalitu Cavnic jsou zjištěné minoritní obsahy $\mathrm{Mn} v$ tetraedritech, jak se zdá, nové. Obsahy $M n$ zřetelně negativně korelují s obsahem $\mathrm{Fe}+\mathrm{Zn}$ (obr. 12), což potvrzuje předpoklad uplatnění $\mathrm{Mn}^{2+}$ spolu s ostatními dvojmocnými prvky v tetraedrické pozici $C$ (Biagioni et al. 2020a). Všechny studované vzorky jsou Zn-dominantní (obr. 13), jedna bodová analýza tetraedritu-(Zn) z ložiska Săcărâmb se již těsně blíží hranici pro Mndominantní člen. Zjištěné obsahy $M n$ nevýrazně pozitivně korelují se zastoupením As $v$ trigonálně pyramidální pozici (obr. 14) a zvýšené zastoupení Mn se zřetelně omezuje na fáze s nižším obsahem Ag (obr. 15).

V části studovaných vzorků byla zjištěna přítomnost malého množství olova v obsazích oscilujících okolo detekčního limitu. Také tento prvek byl dřívějšími autory $v$ analýzách minerálů skupiny tetraedritu mnohokrát konstatován (například v tennantitu z Jáchymova až 0.14 apfu $\mathrm{Pb}$; Velebil, Sejkora 2018). Př́tomnost olova v tetraedritech diskutují Biagioni et al. (2020a), podle nichž je role $\mathrm{Pb}$ při jeho vstupu do krystalové struktury minerálů skupiny tetraedritu problematická a jeho zjištění $v$ analýzách může být způsobeno prítomností velmi jemných inkluzí Pb-bohatých fází. Podobně tomu může být podle těchto autorů také $\mathrm{s}$ cínem, který

Obr. 12 Graf Mn vs. Fe+Zn (apfu) pro studované minerály skupiny tetraedritu z Rumunska.

Obr. 13 Ternární graf Fe - Mn - Zn (at. hodnoty) pro studované minerály skupiny tetraedritu z Rumunska.

Obr. 14 Graf $M n /(M n+F e+Z n)$ vs. $A s /(A s+S b+T e)$ (at. hodnoty) pro studované minerály skupiny tetraedritu z Rumunska.

Obr. 15 Graf Ag vs. Mn (apfu) pro studované minerály skupiny tetraedritu z Rumunska. 
byl ve stopách zjištěn ve všech v této práci studovaných vzorcích (i když často pod detekčním limitem). Tellur by zachycen $v$ malém množství $v$ jediném vzorku a to jen ve dvou analýzách, pritom pro ložiska Botești a Săcărâmb je významná př́tomnost Te charakteristická a jeden ze studovaných vzorků tetraedritu z Botești prímo obsahoval až $50 \mu \mathrm{m}$ velké inkluze hessitu $\mathrm{Ag}_{2} \mathrm{Te}$.

\section{Poděkování}

Předložená práce vznikla za finanční podpory Ministerstva kultury ČR v rámci institucionálního financování dlouhodobého koncepčního rozvoje výzkumné organizace Národní muzeum DKRVO 2019 - 2023/1.II.b, 00023272).

\section{Literatura}

Basu K, Bortnikov NS, Mookherjee A, Mozgova NN, Sivtsov AV, Tsepin Al, VRublevskaja ZV (1984) Rare minerals from Rajpura-Dariba, Rajasthan, India. V: The first recorded occurrence of a manganoan fahlore. $\mathrm{N}$ Jb Miner Abh 149: 105-112

Biagioni C, George LL, Cook NJ, Makovicky E, Moëlo Y, Pasero M, Sejkora J, Stanley ChJ, Welch MD, Bosi F (2020a) The tetrahedrite group: Nomenclature and classification. Am Mineral 105: 109-122

Biagioni C, Sejkora J, Musetti S, Velebil D, Pasero M (2020b) Tetrahedrite-( $\mathrm{Hg})$, a new "old" member of the tetrahedrite group. Mineral Mag, submitted

BURKART-BAUMANN I (1984) Unusual tennantite from Quiruvilca, Peru. In G. Moh: Sulfosalts: observations and mineral descriptions, experiments and applications. $\mathrm{N}$ Jb Miner Abh 150: 25-64.

Damian G., Damian F (2003) Mn-rich tetrahedrites in the Romanian territory. Acta Miner-Petrograph, Abstract Series 1: 24

Doвbe RTM (1992) Manganoan-cadmian tetrahedrite from the Tunaberg Cu-Co deposit, Bergslagen, central Sweden. Mineral Mag 56: 113-115.

George LL, Cook NJ, Ciobanu CL (2017) Minor and trace elements in natural tetrahedrite-tennantite: Effects on element partitioning among base metal sulphides. Minerals 7(2): 17

Huber S, Huber P (1983) Botes und Vulkój-Korábia. Gold und Hessit von den Bergen Botes und Vulkój-Korabia. Lapis 8(10): 28

Chetty R, Prem Kumar DS, Rogl G, Rogl P, Bauer E, Mlchor H, Suwas S, Puchegger S, Giester G, Mallik RC (2015) Thermoelectric properties of a Mn substituted synthetic tetrahedrite. Phys Chem, Chem Phys 1: 1716-1727

Johnson NE, CRaig JR, Rimstidt JD (1986) Compositional trends in tetrahedrite. Can Mineral 24(2): 385-397

Lu X, MorelLi DT, XiA Y, Zhou F, OZOLINS V, CHI H, Zhou X, UHER C (2013) High performance thermoelectricity in earth-abundant compounds based on natural mineral tetrahedrites. Advan Energ Mater 3(3): 342-348

MAKovicky E, KARUP-MøLLER S (1994) Exploratory studies on substitution of minor elements in synthetic tetrahedrite. Part I. Substitution by $\mathrm{Fe}, \mathrm{Zn}, \mathrm{Co}, \mathrm{Ni}, \mathrm{Mn}, \mathrm{Cr}$, $\mathrm{V}$ and $\mathrm{Pb}$. Unit-cell parameter changes on substitution and the structural role of "C $\mathrm{Cu}^{2+“}$. N Jb Miner Abh 167 $89-123$
Moëlo Y, Makovicky E, Mozgova N N, Jambor JL, CoOk N, Pring A, Paar W, Nickel EH, Graeser S, Karup-Møller S, Balić-Žunić T, Mumme WG, Vurro F, Topa D, Bindi L, Bente K, SHImizu M (2008) Sulfosalt systematics: A review report of the sulfosalt sub-committee of the IMA Commission on ore mineralogy. Eur J Mineral 20(1): 7-46

PaUliš P, Beneš M (2005a) Rudní ložiska a mineralogická naleziště rumunského Sedmihradska. Kuttna Kutná Hora $116 \mathrm{pp}$

PAULIŠ P, BEnEš M (2005b) Rudní ložiska a mineralogická naleziště severního Rumunska. Kuttna Kutná Hora $124 \mathrm{pp}$.

Pouchou JL, PICHOIR F (1985) "PAP" ( $\varphi \rho Z)$ procedure for improved quantitative microanalysis. In: ARMSTRONG JT (ed.) Microbeam Analysis: 104-106. San Francisco Press, San Francisco

Suekuni K, Tsuruta K, Kunil M, Nishiate H, Nishibori E, Makı S, Ohta M, Yamamoto A, Koyano M (2013) High-performance thermoelectric mineral $\mathrm{Cu}_{12-\mathrm{x}} \mathrm{Ni}_{\mathrm{x}} \mathrm{Sb}_{4} \mathrm{~S}_{13}$ tetrahedrite. J Appl Phys 113(4): 043712

Suekuni K, Tomizawa Y, OZakı T, Koyano M (2014) Systematic study of electronic and magnetic properties for $\mathrm{Cu}_{12-\mathrm{x}} \mathrm{TM}_{\mathrm{x}} \mathrm{Sb}_{4} \mathrm{~S}_{13}(\mathrm{TM}=\mathrm{Mn}, \mathrm{Fe}, \mathrm{Co}, \mathrm{Ni}$, and $\mathrm{Zn})$ tetrahedrite. J Appl Phys 115(14): 143702

Škácha P, Palatinus L, Sejkora J, Plášil J, Macek I, GoLIÁS V (2016) Hakite from Př́bram, Czech Republic: Compositional variability, crystal structure and the role within the Se - mineralization. Mineral Mag 80: 11151128

ŠKácha P, SeJkora J, PlášIL J (2017) Selenide mineralization in the Príbram uranium and base-metal district (Czech Republic). Minerals 7: 91

ŠKáCHA P, SEJKoRA J, PLÁŠIL J, MAKoviCKY E (2020) Pošepnýite, a new Hg-rich member of the tetrahedrite group from Príbram, Czech Republic. J Geosci, submitted

van Embden J, Latham K, Duffy NW, Tachibana Y (2013) Near-infrared absorbing $\mathrm{Cu}_{12} \mathrm{Sb}_{4} \mathrm{~S}_{13}$ and $\mathrm{Cu}_{3} \mathrm{SbS}_{4}$ nanocrystals: synthesis, characterization, and photoelectrochemistry. J Amer Chem Soc 135(31): 1156211571

Velebil D (2014) Příspěvek k poznání chemismu rtut'ových tetraedritů: lokality Jedová hora (Česko), Rudňany, Rožňava, Nižná Slaná, Slovinky (Slovensko) a Maškara (Bosna a Hercegovina). Bull mineral-petrolog Odd Nár Muz (Praha) 22(1): 131-143

VelebiL D, Losos Z (2008) Rtutí bohatý tetraedrit z Jedové hory u Neřežína a jeho doprovodné minerály. Bull mineral-petrolog Odd Nár Muz (Praha) 16(1): 56-60

VelebIL D, SEJKora J (2018) Bismutem bohaté tennantity z Jáchymova (Česká republika). Bull Mineral Petrolog 26(2): 213-222

Velebil D, Macek I, Soumar J (2016) Příspěvek k poznání chemismu tetraedritů z českých lokalit: Př́bram, Obecnice, Zvěstov, Mníšek pod Brdy, Ratibořské Hory, Stará Vožice, Jáchymov, Kutná Hora a Stříbrná Skalice. Bull mineral-petrolog Odd Nár Muz (Praha) 24(1): 132-143 